\title{
RABIES, PENYEBAB DAN MANAJEMEN PRA-PAJANAN SERTA PASCA-PAJANAN
}

\author{
Hemavalli Ragunathan \\ Fakultas Kedokteran, Universitas Udayana \\ (hemavalliragunathan.hr@gmail.com)
}

\begin{abstract}
ABSTRAK
Rabies adalah penyakit virus akut yang menyebabkan encephalomyelitis fatal pada hampir semua hewan berdarah panas termasuk manusia. Virus ini ditemukan di alam liar dan beberapa hewan domestik, dan ditransmisikan ke hewan lain dan manusia melalui air liur mereka (yaitu berikut gigitan, goresan , jilatan pada kulit rusak dan selaput lendir). Pedoman seluruh kutipan di seluruh dunia bahwa anjing bertanggung jawab untuk sekitar $97 \%$ dari rabies pada manusia, diikuti oleh kucing ( $2 \%$ ) , serigala , musang dan lain-lain ( $1 \%$ ). Penyakit ini terutama ditularkan oleh gigitan anjing gila.
\end{abstract}

Kata Kunci: Rabies,Epidemiologi,Penyebab, Manajemen

\section{RABIES, ETIOLOGY,PRE-EXPOSURE AND POST-EXPOSURE MANAGEMENT}

\section{ABSTRACT}

Rabies is an acute viral disease that causes fatal encephalomyelitis in virtually all the warm-blooded animals including man. The virus is found in wild and some domestic animals, and is transmitted to other animals and to humans through their saliva (i.e. following bites, scratches, licks on broken skin and mucous membrane). Guidelines throughout worldwide quote that dogs are responsible for about $97 \%$ of human rabies, followed by cats $(2 \%)$, jackals, mongoose and others (1\%). The disease is mainly transmitted by the bite of a rabid dog.

Keyword: Rabies, Epidemiology, Causes, Management

LATAR BELAKANG

Rabies disebabkanoleh virus

neurotropikdari genus Lyssavirus. Genus initermasuk virus rabies klasik, dua lyssaviruses kelelawarEropa, kelelawar lyssavirus Australia, dan virus AfrikaDuvenhage. ${ }^{1.2}$ Menurut forum penelitian vaksin dunia WHO, lebih dari 30.000 orang meninggal setiap tahun karena rabies di Asia. Satu orang Asia meninggal setiap 15 menit di mana15 \% cenderung menyerang anak-anak di bawah 15 tahun., ${ }^{1,2}$

Ada 104 kasus rabies padamanusia di Bali selama November 2008 - November 2010.Usia rata-rata pasienadalah 36,6 tahun ( kisaran 3-84 tahun ; Standar Deviasi 20,7 ) , sebagianbesaradalahlaki-laki ( 56,7 \% ), danberasaldaridaerahpedesaan. Hampirsemua (92 $\%$ )kasusmemilikiriwayatgigitananjing. ${ }^{2.3}$

$\begin{array}{lr}\text { Rabies } & \text { adalahinfeksi } \\ \text { padaawalnyahewan } & \text { liar } \\ \text { dansekaranghewandomestik, } & \text { yang }\end{array}$
menyebarkemanusiamelaluigigitandankontakdeng an membrane mukosa.Kebanyakaninfeksi (90 \%) yang ditularkanmelaluihewandomestik (kucingdananjing),

terutamakarenahubunganmerekalebihdekatdenga nmanusia.Setelahmenggigit, virus bereplikasidalamselototdekatdengantempatgigita ndankemudiannaikke system sarafpusatmelaluisarafperifer. ${ }^{2-4}$

Dari sistem sarafpusat, adareplikasi virus padamembran neuron dankemudianditransmisikanlangsung di sinapsiskesarafeferen, dandisimpan di hamper setiapjaringantubuh, termasuk system sarafotonommelaluijalursaraf.Masa inkubasipenyakitdarigigitanbervariasi, 
tapibiasanyaantara $\quad 30 \quad$ dan 90

hari.Gigitanpadakepaladanlehermemiliki masa inkubasi yang lebihpendek (kadangkadangbahkansingkat $\quad \pm \quad 15 \quad$ hari) dibandingkandengangigitanpadatubuhdanekstrem itasbawah, karenasurface arealebihkecildanlebihbanyak neuron. ${ }^{2-4}$ Setelahtransmisi virus rabies, gejala prodromal yang munculadalahgatal, nyeri, atauparestesia di tempatlukagigitan, demam, mialgia, sakitkepala, cepatmarahataudepresi, gangguanpencernaan, radiculopati di tungkai yang tergigit, berlanjutkeensefalopati. Gejala prodromal selanjutnya adalahlumpuhkarena rabies.Rabies Furioustermasukpresentasiklinissepertimudahmar ah, agitasi, hidrofobia, danhiparesthesia.Sementararabies paralitikakanmenyebabkanmunculnyaflaccid paralysis. $^{3-5}$

Sebagian besar rabies

dapatdicegahberkembang lebih parahjikagigitanbinatangdikeloladengantepat. ${ }^{2}$

\section{MANAJEMEN RABIES}

\section{Profilaksis atau ImunisasiPra - Pajanan}

Vaksinasi pra - pajanan dianjurkan untuk orang dengan risiko terus-menerus atauseringpada paparan virus rabies. Misalnya, staf laboratorium, dokter hewan, dan siapa saja yang bekerja dengan hewan dan kehidupanliar harus menerima profilaksis pra - pajanan untuk mengurangi risiko infeksidalam pekerjaan mereka. Termasuk kelompok berisiko tinggi seperti bayi dan anakanakdan juga wisatawan di daerah dengan tingginya insiden rabies dan di mana akses ke perawatan segera atau rabies immunoglobulin terbatas. $^{4-6}$

Rute intradermal memiliki keuntungan menjadi dosis yang hemat, sehingga perlindungan setara sampai dengan $60-80 \%$ dari biaya rute intramuskular, dan membutuhkan hanya satu kunjunganuntuk profilaksis pra - pajanan. Biaya yang rendah meningkatkan kemungkinan pasien akan menyelesaikan profilaksis pasca pajanan. Imunisasiintradermal terhadap rabies digunakan terutama di negara-negara yang direkomendasikan WHO untuk vaksin denganrute ini. $^{3-6}$
Prinsip-prinsip yang memungkinkan vaksinasi intradermal adalah respon yang lebih baik denganvolume yang sama dari antigen ketika ditempatkan dalam kontak dengan sel-sel Langerhans epidermis dan penggunaan beberapa tempat vaksinasi untuk mendapatkan drainase maksimum sel antigen-presenting ke kelenjar getah bening. $^{2-5}$

Kerugian meliputi pelatihan tambahan yang diperlukan untuk memastikan bahwa vaksin ini diberikan dengan benar, dan masalah keamanan tentang penggunaanbotolberulang kali. Rute intradermal tidak dianjurkan untuk profilaksis pra - pajanan pada pasien immunocompromised atau mereka yang memakai klorokuin untuk pengobatan malaria atau profilaksis. ${ }^{2-5}$

Individu menerima profilaksis antimalaria dengan klorokuin atau senyawa terkait harus divaksinasi oleh IM rute, karena respon antibodi mereka untuk vaksinasi intradermal mungkin lebih rendah dari normal. ${ }^{2-4}$

WHO

mengatakanbahwaterdapatduavaksinasiprofilaksis pra-pajanan;melalui intramuskular danmelalui intradermal.Dosissebanyak 0.5 or $1 \mathrm{~mL}$ diberikan, melaluimuskulus deltoid untukinjeksiintramuskular.Sementaradosis 0.1 or $0.2 \mathrm{~mL}$, diberikan pada deltoid atas untuk intradermal. ${ }^{4-6}$

\section{PendekatanPascaPajananuntuk Animal Bites danEksposur Lainnya}

Virus rabies mudah dibunuh oleh sinar matahari, sabun, dan pengeringan.Perawatan luka adalah pencegahan infeksi rabies yang terbaik. Padahewan percobaan, transmisi rabies dapat hampirbenar-benar dicegah dengan perawatan luka lokal yang diberikan dalam3 jam pertama setelah paparan.Hal ini tidak berarti bahwa imunoprofilaksis dapat diabaikan atau tidak dilakukan, tetapi risikodan kebutuhan sangat berkurang dengan perawatan luka yang tepat. ${ }^{5,6}$

Bila memungkinkan, perawatan luka harus mencakup infiltrasidengan anestesi lokal. Luka kemudian harus benar-benardigosok dengan air dan larutan yodium, alkohol 40-70 \%, atau senyawa amonium kuaterner (setrimid0,1 \% BPC), yang semuanya memiliki efek mematikan yang terbukti padavirus rabies. ${ }^{3-6}$ 
Selama perawatan luka, tepi luka harus digosok dan setiap luka tusukan harus dibersihkansecara menyeluruh termasuk bagian terdalam. Setelah digosok,tempat luka harus dibilas dengan garam dan ditutupdengan balutan sederhana. Penggunaan antibiotik yang tepatdanvaksinasi tetanus, harusdiberikan jika diindikasikan. ${ }^{3-6}$

\section{Profilaksis Pasca Pajanan atau Imunisasi sebelum Gejala Onset}

Tujuan dari profilaksis pasca pajanan adalah untuk menetralisirvirus diinokulasi sebelum dapat memasuki sistem saraf.Setelah luka dibersihkan, administrasi antibodi pasif dan imunisasi aktif harus dilakukan. Ada dua jenis immunoglobulin, rabies immune globulin ( RIG ) yang dapat diberikan yang RIG manusia dan RIG equine. . $^{2-5}$

Administrasi HRIG untuk pasien dengan rabies klinis memiliki tujuan pembersihan terhadap infeksi. Hal ini dicapai dengan menggunakan rabies manusia imunoglobulin (HRIG) yang berfungsi dengan menetralkan virus rabies baik lokal dan sistemik dalam minggu pertama sebelum respon tubuh sendiri untuk vaksin. HRIG juga tampaknya meningkatkan respon sel T pasien terhadap vaksin. ${ }^{2-4}$

Dosis awal adalah 20 IU immunoglobulin / kg berat badan, yang harus menyusup di sekitar lokasi luka sebanyak yang bisa dicapai,karena kadar antibodi terhadap virus rabies tidak tinggi setelah pemberian parenteral dari RIG , dan netralisasi lokal virus adalah yang terpenting. Sisanya kemudian disuntikkan intramuskuler ke daerah sejauh mungkin dari tempat vaksinasi. Jika HRIG tidak tersedia, rekomendasi WHO menggunakan imunoglobulin equine dengan dosis 40 IU / kg. Sayangnya HRIG sangat mahal (f 330 untuk pasiendengan BB $70 \mathrm{~kg}$ ), dan dengan demikian tidak sering tersedia di negara-negara dunia ketiga yang membawa risiko rabies tertinggi. ${ }^{1-4}$

Imunisasi aktif terhadap rabies harus dimulai bersamaan dengan pemberian antiserum. Meskipun tidak ada harus dilakukan untuk mendorong imunisasi aktif dan imunisasi pasif pada waktu yang berbeda, jika satu produk yang tersedia sebelum yang lain, itu harus diberikan segera, dan produk kedua harus diberikan bila telah tersedia. Namun, jika RIG tersedia 11 minggu setelah vaksinasi telah dimulai, itu mungkin tidak perlu sebagai respon antibodi yang aktif akan mulai. Jadwal 5 dosis vaksinasi pasca-paparan terhadap rabies diterima secara internasional, dan injeksi intramuskular adalah satu-satunya rute yang dapat diterima. ${ }^{4-6}$

Dosis yang diberikan pada 0, 3, 7, 14, dan 28 hari. Setelah dosis kelima, antibodi yang selalu ada, biasanya pada titer dari 110 IU. Vaksin dan antiserum tidak boleh dicampur atau disuntikkan di tungkai yang sama. Di Amerika Serikat, ada pilihan 3 vaksin yaitu HDCV, vaksin kultur sel embrio ayam dimurnikan, dan vaksin kultur sel paru rhesus janin. Titer harus diukur pada orang imunosupresi, termasuk orang-orang dengan infeksi HIVsetelah vaksinasi untuk memastikan serokonversi yang telah terjadi. Pasien terinfeksi HIV dengan jumlah sel CD41 bawah 300 / mL memiliki respon buruk, dan mungkin perlu dosis tambahan vaksin. ${ }^{3-5}$

Masalah yang paling signifikan adalah reaksi alergi tipe I atau III yang terdiri dari urtikaria, arthritis, dan angioedema, yang terlihat di sekitar $6 \%$ dari pasien yang menerima dosis booster HDCV. Tidak ada pernyataan kontraindikasi, dan vaksinasi aman pada kehamilan. ${ }^{4-6}$

\section{PENCEGAHAN}

Rabies padamanusiadapatdicegah dengan efektif, dengan mengontrol hewansebagaikomponenpentingdalammengurangi risiko pada kesehatanuntukmanusia.Rabies anjingdapatdihilangkandenganmetodepengendalia nmapandan program vaksinasi rabies anjingrutin. ${ }^{4,6}$

\section{KESIMPULAN}

Rabies adalahpenyakit virus akut yang menyebabkan encefalomyelitis fatal pada hampir semuahewanberdarahpanastermasukmanusia. Virus iniditemukan di alam liar danbeberapahewan domestik, danditransmisikankehewan lain danmanusiamelalui air liurmereka (yaituberupa gigitan, goresan, jilatanpadakulitrusakdanselaputlendir). Menurut forum penelitian vaksin dunia WHO, lebih dari 
30.000 orang meninggal setiap tahun karena rabies di Asia. Satu orang Asia meninggal setiap 15 menit di mana15 \% cenderung menjadi anak-anak di bawah 15 tahun.Setelahtransmisi virus rabies, gejala prodromal.Rabies Furioustermasukpresentasiklinissepertimudahmar ah, agitasi,

hidrofobiadanhiparesthesia.Sementararabies paralitikakanmenyebabkanmunculnyaflaccid paralysis. $^{4,5}$

Penanganan rabies terbagimenjadiempat macam.Pertamadalambentuk profilaksis atau imunisasi pra - pajanan, keduaadalahpendekatan pasca pajanan untuk animal bites dan eksposur lainnya, ketigaadalahprofilaksis pasca pajanan atau imunisasi sebelum gejala onset, danterakhiradalahmelaluipencegahan. ${ }^{2,3}$

\section{DAFTAR PUSTAKA}

1. Ni M Susilawathi:Epidemiological and clinical features of human rabies cases in Bali 20082010; 12 March 2012.

2. Yousaf et al:Rabies molecular virology, diagnosis, preventionand treatment Virology Journal 2012; 14 March 2012.

3. Alan C. Jackson: Management of Rabies in Humans; 18 December 2002.

4. Natasha S Crowcroft: The prevention and management of rabies; 13 January 2015.

5. N McKay: Rabies: a review of UK management; 12 April 2005.

6. Alan C Jackson: Update on rabies; Research and Reports in Tropical Medicine; 01 February 2011. 